\title{
Pengembangan Sumber Daya Manusia Berbasis Kompetensi di Kantor Pemerintah Kota Bandar Lampung
}

\author{
NUR EFENDI
}

\begin{abstract}
Jurusan Administrasi Bisnis, Fakultas Ilmu Sosial dan Ilmu Politik, Universitas Lampung
Jalan Sumanteri Brojonegoro No. 1, Gedung Meneng, Bandar Lampung 35145

email: nurefendi10@gmail.com
\end{abstract}

\begin{abstract}
Competence is one of the key variables that determine the performance of an employee. This study aims to provide an overview of competency-based human resource development in the Office of the City of Bandar Lampung. The method used is descriptive with inductive approach. Data collection is done by observation, interviews, and documentation. The data were analyzed qualitatively namely through data reduction, data presentation, and conclusions. The results showed that the competency-based human resource development in the Office of the City of Bandar Lampung not achieve optimal results. This is shown by the results of performance appraisal that does not reflect the actual achievement of an employee. Factors that cause less successful efforts of competency-based human resource development is due to the low culture of learning and development practices that do not associate the results of planning activities, training, assessment, and job-oriented competence development
\end{abstract}

Keywords: competency-based human resources, learning culture, an environment

\begin{abstract}
Abstrak. Kompetensi adalah salah satu variabel kunci yang menentukan kinerja seorang pegawai. Penelitian ini bertujuan memberikan gambaran pengembangan sumberdaya manusia berbasis kompetensi di Kantor Pemerintah Daerah Kota Bandar Lampung. Metode penelitian yang digunakan adalah deskriptif dengan pendekatan induktif. Pengumpulan data dilakukan dengan cara observasi, wawancara, dan dokumentasi. Analisis data dilakukan secara kualitatif, yaitu melalui reduksi data, penyajian data, dan pengambilan kesimpulan. Hasil penelitian menunjukkan bahwa pengembangan sumberdaya manusia berbasis kompetensi di Kantor Pemerintah Kota Bandar Lampung belum mencapai hasil yang optimal. Hal ini terlihat dari hasil penilaian prestasi kerja yang tidak mencerminkan prestasi aktual seorang pegawai. Faktor yang menyebabkan kurang berhasilnya upaya pengembangan sumberdaya manusia berbasis kompetensi ini adalah karena rendahnya budaya belajar dan praktik pengembangan yang tidak mengaitkan antara aktivitas perencanaan hasil, pelatihan, penilaian, dan pengembangan kompetensi berorientasi pekerjaan.
\end{abstract}

Kata kunci: sumberdaya manusia berbasis kompetensi, budaya belajar, lingkungan

\section{Pendahuluan}

Praktik administrasi publik di Indonesia pada umumnya selalu mengikuti perkembangan pemikiran dan teori administrasi. Ada kecenderungan bahwa praktik yang dilakukan selalu mengikuti kisah sukses praktek administrasi dan birokrasi yang terjadi di dunia Barat. Kita jarang berpikir bahwa secara budaya dan sumberdaya, kita berbeda, dan bahkan sangat berbeda dengan mereka. Akibatnya, kita sering merasa frustrasi karena kisah sukses negara lain tidak dapat kita ikuti dan tidak pernah bertanya "mengapa" kita gagal.

Sebenarnya, ada dua hal yang menjadi permasalahan bagi kita dalam mengimplementasikan praktik birokrasi dan manajemen publik. Pertama, kita terlalu cepat mengadopsi sesuatu yang baru secara utuh tanpa memerhatikan kondisi internal kita sendiri. Kedua, kita terlalu cepat menolak suatu ide baru yang diadopsi dari sektor privat, bahkan sebagian besar membuat garis pemisah yang begitu tebal antara

Received: 22 September 2014, Revision: 30 Maret 2015, Accepted: 23 Mei 2015

Print ISSN: 0215-8175; Online ISSN: 2303-2499. Copyright@2015. Published by Pusat Penerbitan Universitas (P2U) LPPM Unisba

Terakreditasi SK Kemendikbud, No.040/P/2014, berlaku 18-02-2014 s.d 18-02-2019 
sektor publik dan sektor privat. Kedua hal ini pada akhirnya membawa kita pada suatu perdebatan tiada akhir yang pada intinya tidak membawa perubahan yang positif terhadap praktik administrasi publik yang ada. Kondisi ini diperparah dengan sistem sentralisasi kebijakan publik yang sangat bergantung pada aktor-aktor politik di tingkat pusat. Akibatnya, ide-ide perbaikan yang datang dari bawah tidak bisa dijalankan karena aparatur pelaksana begitu takut melanggar aturan yang ada. Dalam kenyataannya setiap aktivitas birokrasi dikendalikan oleh aturan, bukan oleh misi dan tujuan organisasi. Padahal, kita tahu bahwa aturan selalu datang terlambat dan sangat sulit untuk dilakukan penyesuaian. Praktik administrasi publik yang dijalankan pada akhirnya tergantung pada faktor kebiasaan yang sudah dianggap sebagai budaya birokrasi.

Praktik administrasi publik seharusnya berorientasi pada masyarakat sebagai customer, dan juga harus diperuntukkan bagi pengembangan organisasi secara internal. Praktik pelayanan publik tidak akan berhasil jika sumberdaya manusia yang memberikan pelayanan tidak dikembangkan kompetensinya. Pengembangan sumberdaya berbasis kompetensi merupakan salah satu hak program pengembangan harus dilakukan oleh pemerintah agar diperoleh aparatur birokrasi yang berkinerja tinggi. Beberapa hasil penelitian juga menunjukkan adanya korelasi positif antara pengembangan sumberdaya manusia dengan kinerja pegawai (Dipang, 2013: 1080; Hersona et al, 2012: 728)

Artikel ini bertujuan untuk memberikan gambaran pengembangan sumberdaya manusia berbasis kompetensi di Kantor Pemerintah Daerah Kota Bandar Lampung. Tulisan ini merupakan refleksi dari salah satu dari sekian banyak permasalahan sumberdaya manusia yang dihadapi oleh Pemerintah Daerah. Pemilihan Pemerintah Daerah Bandar Lampung sebagai objek penelitian didasarkan pada fakta bahwa Bandar Lampung adalah ibukota Propinsi Lampung yang secara usia dapat dikatakan "sudah dewasa." Namun, praktik kepegawaian yang terjadi sama sekali belum menunjukkan kedewasaan tersebut.

Dalam konteks kepegawaian daerah, rendahnya kinerja pegawai Pemerintah Daerah bukanlah hal baru. Duadji (2012: 202) mengatakan bahwa,

Kondisi manajemen pemerintah dan penyelenggaraan birokrasi publik masih banyak kelemahannya. Penetapan kedisiplinan, penghematan, budaya kerja, kualitas pelayanan, netralitas birokrasi, sampai dengan penerbitan berbagai peraturan perundangundangan pendukung atau dengan kata lain aspek restrukturisasi dan revitalisasi, masih kental memperlihatkan wajah buramnya. Peningkatan kualitas kinerja aparatur dan pelayanan publik masih jauh dari harapan dan keinginan masyarakat.

Permasalahan lain yang juga sering menjadi sorotan adalah kompetensi aparat birokrasi yang dihubungkan dengan kualitas pelayanan yang diberikan. Suka atau tidak, masyarakat menilai bahwa pengangkatan pegawai di lingkungan kantor Pemda Kota Bandar Lampung sebagian besar kurang memerhatikan faktor kompetensi. Rekruitmen pegawai dilakukan tanpa memperhatikan kebutuhan organisasi, proses seleksi yang sarat dengan KKN dan uang pelicin, penempatan pegawai yang tidak sesuai dengan latar belakang pendidikan dan pengalamannya, merupakan beberapa hal yang cukup mencolok dalam praktik administrasi kepegawaian daerah.

Oleh karena itu, rendahnya kinerja pegawai kantor Pemda, jika dikaitkan dengan faktor kompetensi, menjadi sangat beralasan. Pernyataan ini diperkuat dengan hasil penelitian Winanti (2011) yang menunjukkan bahwa kompetensi secara signifikan mempunyai pengaruh positif terhadap kinerja pegawai dan Nawawi (2012) yang juga menyimpulkan bahwa motivasi dan kompetensi berpengaruh terhadap kinerja pegawai.

Tanpa mengenyampingkan perilaku negatif yang diperlihatkan pegawai Kantor Pemda Kota Bandar Lampung, rendahnya kinerja pegawai juga dipengaruhi oleh kompetensi yang mereka miliki. Artikel ini tidak ditujukan untuk mengevaluasi kebijakan Pemda dalam bidang kepegawaian, namun lebih pada upaya pengembangan model sumberdaya manusia berbasis kompetensi di Kantor Pemerintah Daerah Bandar Lampung.

Penelitian ini memiliki arti penting karena: (1) fakta menunjukkan bahwa pegawai yang telah lama bekerja kehilangan $30 \%-50 \%$ keterampilan yang diperlukan untuk menunjukkan kinerja; (2) data industri menunjukan bahwa banyak pegawai yang tidak memahami alasan kenapa mereka harus menunjukkan kinerja yang lebih baik; (3) sebanyak $80 \%$ jumlah rupiah yang dikeluarkan untuk pelatihan tidak fokus terhadap kebutuhan (Manopo, 2011: 12). 
Selain itu, masalah kompetensi ini juga disinggung dalam pasal 17 ayat 2 Undangundang nomor 43 tahun 1999 tentang PokokPokok Kepegawaian yang berbunyi:

Pengangkatan Pegawai Negeri Sipil dalam suatu jabatan dilaksanakan berdasarkan prinsip profesionalisme sesuai dengan kompetensi, prestasi kerja, dan jenjang pangkat yang ditetapkan untuk jabatan itu serta syarat objektif lainnya tanpa membedakan jenis kelamin, suku, agama, ras, atau golongan". Oleh sebab itu, adalah penting bagi Pemerintah Daerah untuk mengembangkan sumberdaya manusia berbasis kompetensi agar pegawai menunjukkan kinerja yang semakin baik.

Istilah kinerja seringkali digunakan secara bergantian dengan istilah performance. Ada beberapa definisi tentang kinerja atau performance. Rue dan Byars (dalam Yudoyono, 2001: 158) mengatakan kinerja sebagai the degree of accomplishment. Dikatakan oleh Rue dan Byars, konsep kinerja dapat didekati dengan dua pendekatan, yaitu the engineering approach dan the economis marketplace approach.

Menurut the engineering approach, kinerja diartikan sebagi rasio antara sumberdaya yang digunakan (input) dengan standar unit-unit kerja yang dihasilkan (output). Sedangkan menurut the economis marketplace approach, kinerja berkaitan dengan tingkat produksi yang dihasilkan dengan penggunaan sumberdaya tertentu (Widodo, 2001: 207). Dengan kata lain, dua pendekatan terhadap kinerja ini mengarah pada konsep efisiensi dan efektifitas. Lebih jauh, menurut Wahyusumidjo (1987: 177),

Performance merupakan hasil interaksi antara motivasi $(\mathrm{m})$, kemampuan (k), dan persepsi $(p)$. Orang yang motivasinya tinggi tetapi rendah kemampuannya, akan menghasilkan performance yang rendah. Dan orang yang motivasinya rendah dan kemampuannya juga rendah sudah jelas akan menghasilkan performance yang rendah juga."

Apa yang dikatakan Wahyusumidjo ini hampir sama dengan yang dikatakan Hellriegel, et al (2001: 132) dan Keith Davis (dalam Mangkunegara, 2010: 13) bahwa performance adalah fungsi dari kemampuan dan motivasi. Menurut Hellriegel, ..., "no task can be performed successfully unless the person who is to carry it out has the ability to do so". Menurut Robbins (2001: 37) ability adalah "an individual's to perform the various tasks in a job". Selanjutnya menurut Robbins, ability terdiri atas intellectual abilities dan physical abilities. Employee performance akan meningkat ketika ada kesesuaian antara kemampuan yang tinggi dengan pekerjaan (Robbins, 2001: 38) Menurut Mangkunegara (2010: 13), secara psikologis, ability terdiri atas kemampuan potensi (IQ) dan kemampuan reality (knowledge + skill).

Beberapa definisi di atas menekankan bahwa kinerja adalah tingkat pencapaian yang dihasilkan oleh seorang pegawai. Pencapaian hasil ini dapat dipengaruhi oleh banyak variabel. Seperti dikatakan Wahyusumidjo, Hellriegel, dan Davis, kemampuan dan motivasi merupakan dua variabel yang turut memengaruhi kinerja seorang pegawai.

Profiles International.com dalam situsnya mengemukakan kinerja pegawai dapat diukur dengan menggunakan indikator (1) Productivity; (2) Quality of work; (3) Initiative; (4) Teamwork; (5) Problem solving; (6) Response to stress and conflict; (7) Employee performance development. Sebenarnya, ada banyak faktor yang berkorelasi dengan kinerja individu, seperti organizational justice, work engagement, dan public service motivation (Jankingthong \& Rurkkhum, 2012: 115)

Agar kinerja yang dihasilkan oleh pegawai membawa dampak dalam proses kepegawaiannya, maka kinerja tersebut harus dinilai dan diukur. Ada banyak metode penilaian dan pengukuran kinerja yang dapat digunakan oleh organisasi. Beberapa pengukuran kinerja pegawai yang digunakan di antaranya adalah Key Performance Indicators (KPI) seperti dilakukan oleh Iveta (2012: 117) dan Total Performance Scorecard (Rampersad, 2006).

Penilaian kinerja dimaksudkan agar organisasi mendapatkan umpan balik tentang apa yang telah dilakukan pegawai dan action apakah yang perlu dilakukan agar kinerja pegawai tersebut dapat dipertahankan atau malah kalau perlu ditingkatkan. Atau dengan kata lain, organisasi harus melakukan pengembangan kompetensi berbasis pekerjaan untuk mencapai tingkat kinerja pegawai yang lebih tinggi. Oleh karena itu, indikator yang digunakan dalam penilaian kinerja harus benar-benar terukur dan berkaitan dengan pekerjaan.

Terkait dengan kompetensi, Byham, et al (1996) yang dikutip oleh Manopo (2011: 12) menyatakan bahwa kompetensi merupakan sekumpulan perilaku spesifik yang dapat diamati dan dibutuhkan oleh seseorang untuk sukses dalam melakukan peran dan mencapai target perusahaan. Selanjutnya dikatakan oleh Byham, et al, bahwa model kompetensi menggambarkan kombinasi 
perilaku antara pengetahuan, keterampilan, dengan karakteristik yang diperlukan untuk menunjukkan perannya dalam organisasi secara efektif dan kinerja yang sesuai di dalam organisasi. Spencer and Spencer yang dikutip Manopo menyatakan bahwa kompetensi adalah

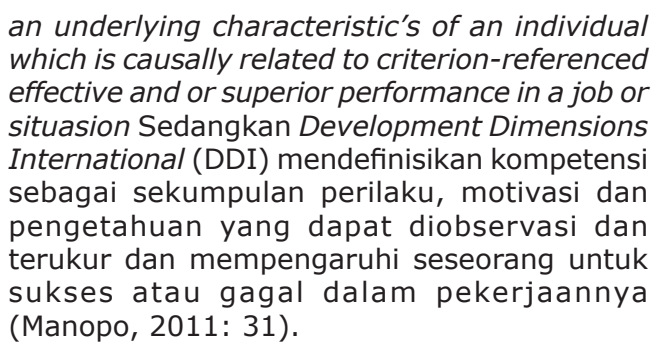

Hampir sama dengan Spencer and Spencer, Dubois, et al (2004: 22) mangatakan bahwa competency as a characteristic that underlies successful performance.

Dari beberapa definisi di atas terdapat satu benang merah yang menegaskan bahwa kompetensi merupakan suatu perilaku yang dapat diobservasi dan diukur. Perilaku yang dapat diamati ini dapat saja diwujudkan dalam bentuk pengetahuan, keterampilan, pengalaman. Namun demikian, kompetensi tidaklah terbentuk dengan cara sederhana seperti yang diungkapkan di atas. Selain perilaku yang terlihat di permukaan, kompetensi sebenarnya memiliki kedalaman yang sulit diduga. Kompetensi ibarat sebuah gunung es di mana yang terlihat ke permukaan hanyalah perilaku yang bisa diamati, sedangkan di bawah permukaan terdapat potensi yang sangat besar yang justru menentukan kompetensi sesungguhnya yang dimiliki seseorang, seperti terlihat pada Gambar 1.

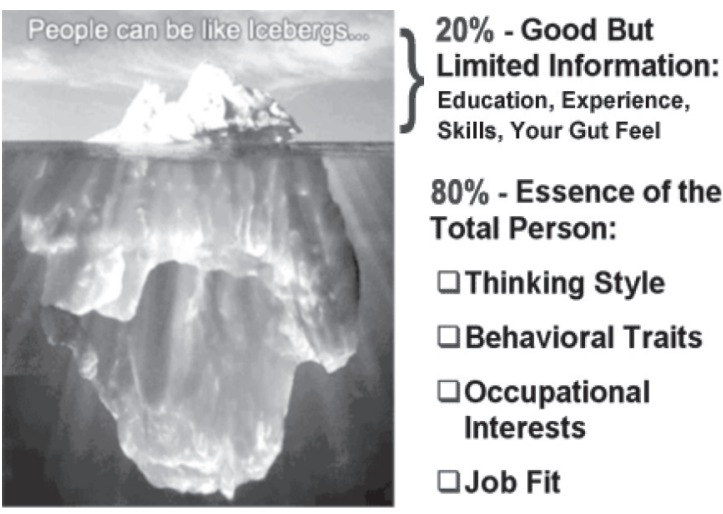

Gambar 1 Gunung Es Kompetensi

Sumber: http://www.assessmentspecialists.com/ images/totalperson.gif, diakses 15 Pebruari 2013
Hal sama juga diungkapkan oleh Manopo (2011: 13) dengan menggambarkan kompetensi ini dalam bentuk piramida di mana puncaknya merupakan perilaku yang terlihat ke permukaan.

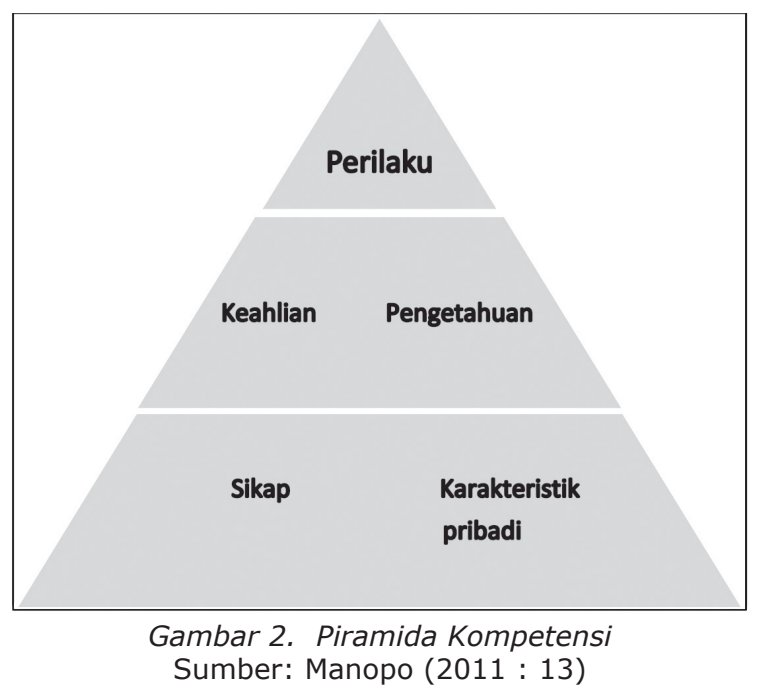

Secara umum, kompetensi sendiri dapat dipahami sebagai sebuah kombinasi antara keterampilan, atribut personal, dan pengetahuan yang tercermin melalui perilaku kinerja yang dapat diamati, diukur ,dan dievaluasi. Dalam sejumlah literatur, kompetensi sering dibedakan menjadi dua tipe, yakni soft competency atau jenis kompetensi yang berkaitan erat dengan kemampuan mengelola proses pekerjaan, hubungan antar manusia, serta membangun interaksi dengan orang lain. Tipe kompetensi yang kedua sering disebut hard competency atau jenis kompetensi yang berkaitan dengan kemampuan fungsional atau teknis suatu pekerjaan. Dengan kata lain, kompetensi ini berkaitan dengan seluk beluk teknis yang berkaitan dengan pekerjaan yang ditekuni. (Antariksa, 2007)

Dikatakan oleh Byham, subsistem dari kompetensi adalah selection, promotion, training and development, performance management, and career planning (Byham, tt: 9). Oleh sebab itu, peningkatan kinerja manajemen sumberdaya manusia dapat diciptakan melalui integrasi subsistem ini ke dalam sebuah sistem yang lebih besar yang disebut dengan Competency-Based Human Resource Management (CBHRM).

CBHRM adalah suatu pola pendekatan di dalam membangun suatu sistem manajemen sumber daya manusia yang handal dengan memanfaatkan kompetensi sebagai titik sentralnya. Menurut Byham (tt: 6-7), ada 4 
(empat) keunggulan dari penerapan sistem sumberdaya manusia berbasis kompetensi ini, yaitu:

(1) Decreased communication, training, and administration time; (2) Subsystems validate one another; (3) Subsystems reinforce one another; (4) The entire system and each subsystem can be validated using a contentoriented validation strategy (that is, the subsystem can be related to defined job requirements).

Untuk mencapai hasil yang optimal, strategi CBHRM ini harus dilakukan secara terintegrasi dengan program-program lainnya dalam kerangka pengembangan sumberdaya manusia, seperti rekruitmen dan seleksi, pelatihan, promosi, dan lain-lainnya.

Satu hal yang lebih penting lagi adalah bahwa strategi ini selain bermuara pada pencapaian kinerja pegawai yang tinggi, juga berimplikasi pada kebijakan remunerasi bagi pegawai. Kebijakan remunerasi ini harus dirancang sejak awal agar pegawai sebagai subjek yang menjalani program bisa mengukur dan memperkirakan besarnya remunerasi yang bisa didapatkan dengan kinerja dan kompetensi yang mereka hasilkan.

Inti dari pengembangan SDM berbasis kompetensi ini adalah kompetensi jabatan yang disyaratkan dibandingkan dengan kompetensi yang dimiliki individu. Semua aspek manajemen sumberdaya manusia selalu dikaitkan dengan kompetensi yang dimiliki dan dibutuhkan untuk menduduki suatu jabatan.

Dalam menerapkan sistem CBHRM secara terintegrasi, maka organisasi harus melaksanakan setiap aktivitas kepegawaiannya berdasarkan kompetensi, baik dalam hal selection, promotion, training and development, performance management, and career planning (Byham, tt: 9).

Meskipun CBHRM seringkali diimplementasikan pada organisasi privat, tidak berarti bahwa konsep ini menjadi tabu bagi organisasi publik seperti organisasi Pemerintah Daerah. Apalagi pemerintah telah berkomitmen untuk melakukan reformasi birokrasi dari pusat sampai ke daerah. Misi pelayanan yang harus dilakukan oleh birokrasi di daerah menuntut mereka berkinerja tinggi dan dengan demikian dibutuhkan pegawai dengan kompetensi yang sesuai dengan kebutuhan kerja. Untuk mencapai hal ini dibutuhkan sistem kepegawaian daerah yang mampu mendorong penciptaan dan peningkatan kompetensi pegawai melalui pelaksanaan fungsi-fungsi manajemen sumberdaya manusia yang terintegrasi. Langkah awal untuk mengimplementasikan manajemen sumber daya manusia terintegrasi ini adalah dengan melakukan penilaian kinerja pegawai secara objektif, terukur, dan akuntabel.

Artikel ini menggunakan tipe deskriptif untuk mendeskripsikan pengembangan sumberdaya manusia berbasis kompetensi di Kantor Pemerintah Kota Bandar Lampung. Pendekatan yang digunakan dalam penelitian ini adalah pendekatan induktif dengan metode kualitatif. Pengumpulan data dilakukan dengan cara observasi, wawancara, dan dokumentasi. Informan dalam penelitian ini adalah Kepala Badan Kepagawaian Daerah, Kepala Badan Diklat, dan pegawai negeri di Kantor Pemerintah Kota Bandar Lampung. Keabsahan data diuji dengan melakukan triangulasi sumber. Analisis data dilakukan dengan cara reduksi data, penyajian data, dan pengambilan kesimpulan.

\section{Kinerja Pemda Kota Bandar Lampung dengan Metode Penilaian "Self As- sessment"}

Pengembangan sumberdaya manusia ditujukan untuk meningkatkan kemampuan pegawai dalam melaksanakan tugas saat ini dan yang akan datang. Untuk mengetahui apakah tujuan pengembangan ini telah tercapai atau belum akan terlihat dari hasil penilaian kinerja pegawai. Terkait dengan konteks penelitian ini, penilaian kinerja pegawai negeri di Kantor Pemerintah Kota Bandar lampung secara umum masih berpegang pada Peraturan Pemerintah Nomor 10 tahun 1979 tentang Penilaian Pelaksanaan Pekerjaan Pegawai Negeri Sipil.

Secara teknis, kebijakan penilaian kinerja Pegawai Negeri Sipil dirumuskan dalam suatu Daftar Penilaian Pelaksanaan Pekerjaan (DP3). Meskipun unsur penilaian yang terdapat dalam DP3 ini telah cukup baik, namun dalam pelaksanaannya seringkali terjadi penyimpangan, sehingga hasil penilaian tidak mencerminkan kinerja pegawai yang sesungguhnya. Apalagi unsur-unsur penilaian tersebut sangat rentan dengan subjektivitas penilaian atasan, sehingga seringkali menimbulkan ketidakpuasan pada pegawai. Sebagian besar pegawai tidak melihat pentingnya kinerja yang baik bagi kemajuan karier mereka karena sistem karier dan promosi menjadi hak prerogatif Kepala Daerah atau pejabat yang berkuasa di daerah. 
Penelitian tentang kinerja pegawai Kantor Pemda Kota Bandar Lampung pada tahun 2011 dengan metode penilaian self assessment menghasilkan kesimpulan sebagaimana terlihat pada Tabel di bawah ini.

Tabel 1

Hasil Penilaian Kinerja Pegawai Kantor Pemda Kota Bandar Lampung

\begin{tabular}{|c|l|l|}
\hline No & Indikator Kinerja & Hasil Penilaian \\
\hline 1 & Produktivitas & Tinggi \\
\hline 2 & Kuantitas & Baik \\
\hline 3 & Pengetahuan & Baik \\
\hline 4 & Kualitas & Baik \\
\hline 5 & $\begin{array}{l}\text { Adaptasi dan } \\
\text { Fleksibilitas }\end{array}$ & Baik \\
\hline 6 & Kerjasama & Sangat Baik \\
\hline 7 & Tanggung Jawab & Sangat Baik \\
\hline 8 & Komunikasi & Sangat baik \\
\hline
\end{tabular}

Sumber: Efendi, 2011

Berdasarkan hasil penelitian ini terlihat jelas bahwa pegawai yang bekerja di Kantor Pemda Kota Bandar Lampung memiliki persepsi yang sangat tinggi dengan kinerja mereka. Hasil self assessment ini tidak sesuai dengan fakta bahwa banyak keluhan masyarakat berkaitan dengan cara kerja dan kinerja pegawai pemda yang tidak memuaskan. Hal ini membuktikan adanya kesenjangan di mana tidak ada kesesuaian antara kinerja riil dengan hasil penilaian serta persepsi pegawai tentang kinerja mereka. Kesenjangan ini dapat disebabkan oleh beberapa variabel, diantaranya adalah tingginya persepsi diri pegawai tentang kinerja mereka dan alat ukur yang tidak valid.

Namun di atas semua alasan ini, rendahnya kompetensi pegawai dalam melaksanakan pekerjaannya menjadi salah satu variabel kunci yang menyebabkan rendahnya kualitas pelayanan yang diberikan oleh pegawai Pemda Bandar Lampung di samping sistem penilaian kinerja yang lebih cenderung subjektif dan kurang edukatif. Oleh karena itu, sangat penting bagi pimpinan daerah untuk menerapkan sistem penilaian kinerja yang berbasis kompetensi, sehingga ada kesamaan persepsi antara pegawai yang dinilai, pejabat penilai, serta hasil yang disepakati oleh kedua belah pihak.

Hasil penelitian menunjukkan bahwa kinerja pegawai Kantor Pemda Kota Bandar Lampung berada pada angka 3,6 dalam skala
5, dan terdapat sebanyak $62,07 \%$ pegawai yang memiliki persepsi bahwa mereka telah melakukan pekerjaan dengan sangat baik (Efendi, 2011). Hasil ini tidak terlalu berbeda dengan hasil penilaian DP3 pegawai yang cenderung semakin meningkat dari tahun ke tahun. Meskipun sebagian besar pegawai mempersepsikan kinerja mereka sangat baik, namun hal ini tidak tercermin dalam perilaku kerja sehari-hari. Berbagai perilaku negatif masih banyak terlihat pada aparat birokrasi, seperti tidak disiplin, datang terlambat, sering keluar pada jam-jam kerja, dan perilaku mangkir dari pekerjaan. Perilaku negatif ini tentunya tidak akan pernah memenuhi standar produktivitas kerja yang seharusnya dipenuhi oleh setiap pegawai.

Meskipun demikian, rendahnya kinerja sebagian PNS yang bekerja di lingkungan Pemda Kota Bandar Lampung ternyata tidak terlihat dari hasil penilaian prestasi kerja mereka. Penilaian prestasi kerja PNS dengan menggunakan format Daftar Penilaian Prestasi Pegawai (DP3) masih belum bisa menggambarkan kondisi kerja yang sesunguhnya dari seorang PNS.

Ada kecenderungan bahwa skor hasil penilaian dalam DP3 tidak boleh turun, dan bahkan harus naik. Hasil wawancara dengan beberapa pejabat eselon III di BKD menunjukkan bahwa sangat sulit bagi mereka untuk melakukan penilaian prestasi kerja secara objektif karena format DP3 sudah jelas dan tidak bisa diubah. Bahkan, di beberapa kabupaten di Lampung, seorang pegawai bisa mengisi sendiri nilai DP3-nya dan atasan tinggal tanda tangan.

Fakta ini semakin menunjukkan betapa lemahnya mekanisme penilaian prestasi kerja, sehingga kinerja pegawai tidak dapat dipotret secara objektif. Hasil penilaian terhadap pegawai yang rajin dan malas hampir tidak ada bedanya. Hal ini sudah sering dikeluhkan oleh sebagian pegawai yang merasa "dicurangi" oleh praktik-praktik penilaian tidak sehat yang terjadi di lingkungan Kantor Pemda Kota Bandar Lampung.

\section{Pengembangan Kompetensi, Pegawai Pemerintah Lampung}

Kinerja pegawai Pemerintah Daerah Kota Bandar Lampung seperti diuraikan di atas ternyata terkait dengan upaya pengembangan kompetensi sumberdaya manusia yang telah dilakukan. Hasil penelitian ini menunjukkan bahwa upaya pemerintah daerah dalam rangka meningkatkan kompetensi pegawai 
masih terbatas pada kegiatan-kegiatan yang bersifat in the job training dan off the job training. Meskipun tidak terlalu banyak, namun ada beberapa pegawai yang dikirim untuk mengikuti pelatihan teknis dan kedinasan di berbagai instansi pemerintah lainnya. Bahkan, juga ada pegawai negeri yang mendapatkan tugas belajar di berbagai perguruan tinggi dalam rangka melanjutkan studi magister atau doktor. Namun sekali lagi, upaya ini belum menunjukkan hasil yang nyata bagi peningkatan kinerja pegawai di Kantor Pemerintah Kota Bandar Lampung.

Ada satu hal yang sangat krusial dan tidak mendapat perhatian dari Pemerintah Daerah, yaitu mengaitkan satu aktivitas manajemen sumberdaya manusia dengan aktivitas lainnya. Pengembangan pegawai yang dilakukan selama ini masih bersifat parsial dan kurang memerhatikan keterkaitannya dengan aspek manajemen sumberdaya manusia lainnya. Sebagai contoh, diklat teknis bagi pegawai kurang memerhatikan kebutuhan organisasi secara keseluruhan dan lebih terkesan rutinitas. Kondisi ini tentunya sangat berpengaruh terhadap kinerja pegawai pada saat bekerja.

Inti dari pengembangan sumberdaya manusia berbasis kompetensi pada Kantor Pemerintah Daerah Kota Bandar Lampung menunjukkan pentingnya transfer pengetahuan dalam arti yang sesungguhnya pada organisasi pemerintah daerah.

Transfer pengetahuan ini tidak bisa terjadi hanya dengan mengandalkan diklatdiklat teknis, namun harus dilakukan dalam keseharian pegawai, melalui learning by doing. Hal ini juga dinyatakan oleh Khan, et al (2012: 43) bahwa pengembangan sumberdaya manusia dalam perspektif organisasi secara sempit difokuskan pada fungsi pembelajaran, pendidikan, pelatihan, dan pengembangan sumber daya manusia untuk dipilih dan direkrut untuk mengidentifikasi, menjamin, dan membantu untuk mengembangkan kompetensi kunci yang memungkinkan individu melakukan pekerjaan saat ini atau masa depan. Dengan demikian, organisasi pemerintah daerah sekaligus juga harus mengembangkan manajemen pengetahuan agar mendukung terciptanya lingkungan yang kondusif untuk menerapkan model sumberdaya manusia berbasis kompetensi ini.

Manajemen Pengetahuan yang dimaksudkan adalah a process of identifying, capturing, and leveraging the collective knowledge in an organization to help the organization compete, demikian dikatakan Von Krough, (1999) yang dikutip Alavi \& Leidner (2001: 113). Manajemen Pengetahuan ini dimaksudkan untuk meningkatkan innovativeness and responsiveness pegawai (Alavi \& Leidner, 2001: 113).

Secara lebih khusus, Aktharsha (2010: 65) menyatakan bahwa manajemen pengetahuan merupakan suatu proses organisasi yang spesifik dan sistemik untuk mengumpulkan, mengorganisasi, dan mengomunikasikan pengetahuan tacit dan eksplisit kepada pegawai, sehingga pegawai lainnya dapat menggunakan agar lebih efektif dan produktif dalam bekerja. Dalam pandangan manajemen pengetahuan, setiap individu pada dasarnya memiliki tacit knowledge. Pengetahuan inilah yang harus digali dalam siklus pengembangan kompetensi pegawai, sehingga pengetahuan yang semula bersifat tacit bisa diwujudkan menjadi pengetahuan yang bersifat eksplisit. Namun, hal ini tidak akan mudah diterapkan karena belum terciptanya kondisi yang kondusif yang memungkinkan berkembangnya budaya belajar di kalangan pegawai.

Secara teoretis, ada dua pendekatan pengembangan kompetensi, yaitu kompetensi dari nol dan pengembangan kompetensi dari model yang sudah ada (Manopo, 2011: 17). Dalam konteks organisasi Pemda Kota Bandar Lampung, pendekatan yang memungkinkan untuk digunakan adalah pengembangan kompetensi yang kedua. Hal ini dilakukan dengan asumsi bahwa organisasi Pemda telah memiliki cukup data tentang kompetensi pegawai yang dimiliki.

Oleh sebab itu, yang harus dilakukan sekarang adalah mengembangkan kompetensi pegawai berbasis pekerjaan (Rampersad, 2006: 187). Di sini, penekanannya terletak pada pengembangan kompetensi berorientasi pekerjaan pegawai dan pejabat atasan. Pengembangan ini akan membuat mereka bisa bekerja dengan benar karena pengembangan dan pendidikan mereka dilakukan secara bertahap, mutu kinerja mereka akan meningkat, dan kemampuan mereka untuk menghasilkan kinerja organisasi yang diinginkan dapat dimanfaatkan secara optimal.

\section{Lingkaran Deming (Fungsi "Plan, Do, Check, dan Action")}

Pengembangan kompetensi berorientasi pekerjaan yang dimaksud di atas dapat mengikuti lingkaran Deming yang terdiri atas 
fungsi Plan, Do, Check, lingkaran Deming yang terdiri atas fungsi Plan, Do, Check, dan Action.

Mengacu pada lingkaran Deming, siklus pengembangan kompetensi pegawai dilakukan meliputi empat aktivitas, yaitu perencanaan hasil, pelatihan, penilaian, dan pengembangan kompetensi berorientasi pekerjaan (Rampersad, 2006: 190).

Tahap perencanaan dilakukan dengan menciptakan kesepakatan hasil berdasarkan tujuan kinerja dan pemilihan seperangkat kompetensi yang mendukung tujuan-tujuan itu antara pegawai dengan atasan. Dalam tahap ini, rencana kinerja perorangan disiapkan bersama dengan atasan langsung. Berdasarkan rencana kerja ini, dibuat kesepakatan berkala antara pegawai dengan atasan tentang perwujudan kinerja dan tujuan pengembangan. Dalam rapat perencanaan ini juga dibuat kesepakatan tentang penggunaan kompetensi yang telah dipilih untuk mencapai kinerja yang telah disepakati.

Tahap pelatihan, pegawai dan atasan bertemu secara berkala untuk membahas kemajuan pegawai dalam pencapaian kinerja.Setiap pegawai dipandu dalam menerapkan kompetensinya. Dalam tahap inilah kesepakatan tentang kompetensi yang sudah dipilih pada tahap perencanaan diuji dan disesuaikan dengan tuntutan kinerja. Pelatihan juga memberi peran kepada atasan untuk memberikan umpan balik atas penerapan kompetensi dalam pencapaian kinerja individu.

Tahap penilaian, dilakukan melalui penilaian formal yang dilakukan setelah periode tertentu untuk memastikan apakah semua kesepakatan kompetensi telah dipenuhi oleh seorang pegawai, apakah hasil yang disepakati telah dicapai, dan jika sudah, bagaimana cara perwujudannya. Tahap penilaian harus secara detil menunjukkan kemajuan pegawai dalam bidang pekerjaannya.

Tahap pengembangan, kompetensi berorientasi pekerjaan mencakup pengembangan kompetensi pegawai melalui kursus, pelatihan pekerjaan, pendampingan

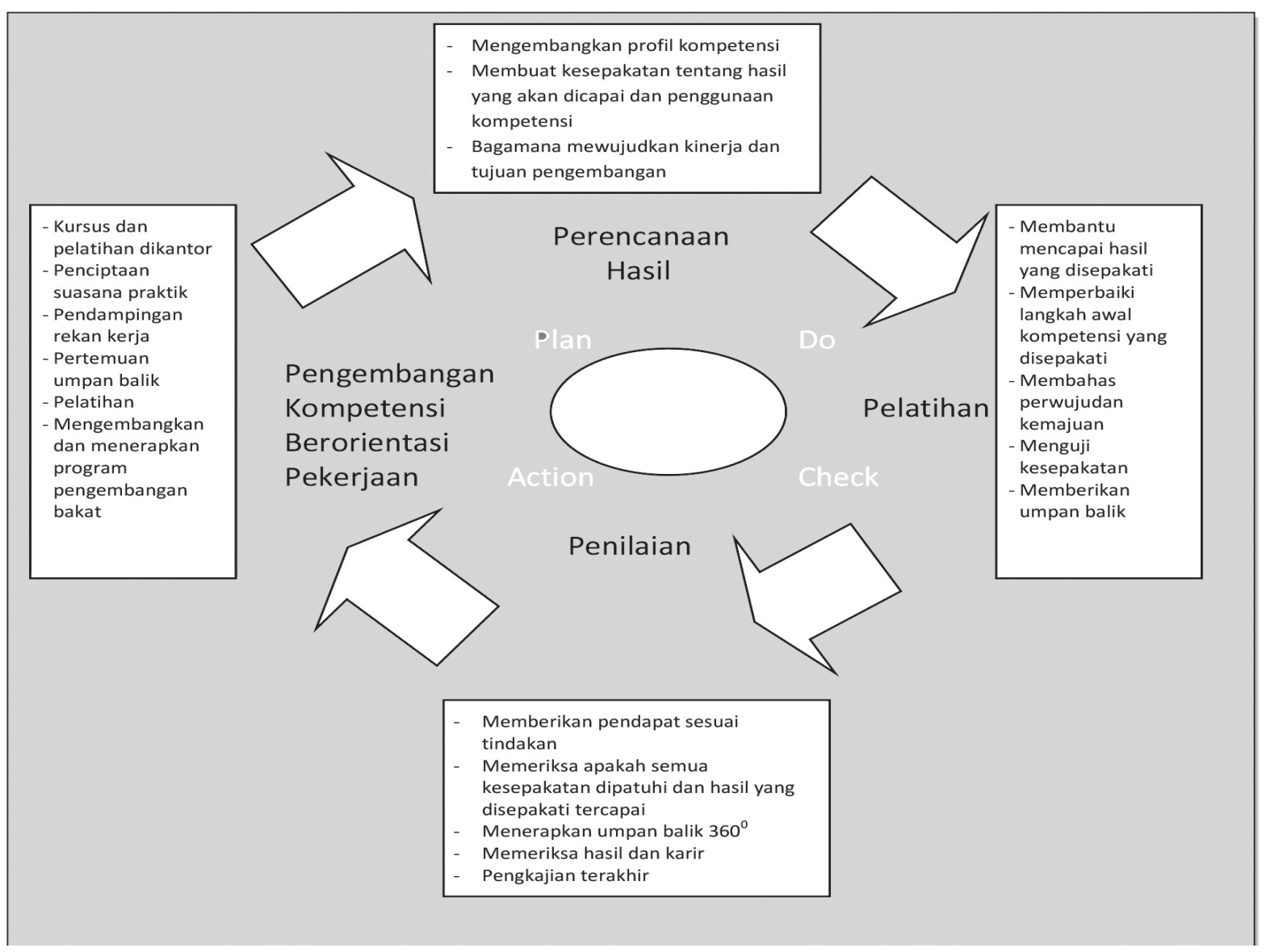

Gambar 2 Siklus Pengembangan Kompetensi Pegawai Kantor Pemda Kota Bandar Lampung dengan Menggunakan Model Rampersad

Sumber: Model Rampersad, 2006: 192 
rekan kerja yang berpengalaman, program pengembangan bakat, dan sebagainya. Tahap ini merupakan tindak lanjut dari hasil penilaian implementasi kompetensi pada pencapaian kinerja pegawai, sehingga kompetensi pegawai selalu mengalami perkembangan sesuai dengan tuntutan kinerja yang disepakati antara pegawai dengan atasan.

Implementasi aktivitas dari siklus pengembangan kompetensi ini dalam konteks kepegawaian di Pemda Bandar Lampung dapat dilihat pada Gambar 2 yang merupakan siklus pengembangan kompetensi yang didasarkan pada model Rampersad dan lingkaran Deming. Di sini, aktivitas perencanaan hasil, pelatihan, penilaian, dan pengembagaan kompetensi, diuraikan lagi menjadi aktivitasaktivitas yang lebih spesifik, sehingga dapat dioperasionalisasikan.

Pengembangan sumberdaya berbasis kompetensi ini diharapkan mampu meningkatkan kinerja pegawai Kantor Pemda Kota Bandar Lampung secara efektif. $\mathrm{Hal}$ ini didasarkan pada pandangan bahwa tindakan dan perilaku spesifik yang efektif akan dapat menghasilkan kinerja yang efektif (Boyatzis, 1982: 13). Kinerja yang efektif dari pekerjaan adalah pencapaian hasil tertentu yang dituntut oleh pekerjaan melalui tindakan tertentu dengan tetap menjaga atau konsisten dengan kebijakan, prosedur, dan kondisi lingkungan organisasi (Boyatzis, 1982: 13). Untuk mengetahui apakah suatu pekerjaan telah mencapai kinerja yang efektif, maka perlu dilakukan penilaian oleh suatu unit organisasi (Boyatzis, 1982: 11). Boyatzis (1982: 13) juga mengatakan bahwa tindakan dan perilaku pegawai akan dipengaruhi oleh tuntutan kerja, lingkungan organisasi, dan kompetensi individu. Hal ini berarti bahwa untuk menciptakan perilaku kerja yang efektif, dibutuhkan lingkungan organisasi yang mendukung ke arah pengembangan bakat dan kemampuan pegawai serta lingkungan yang kondusif. Lingkungan organisasi dapat digambarkan dalam sejumlah faktor yang berbeda (Boyatzis, 1982: 18), seperti kondisi pemerintahan, budaya kerja, budaya belajar dalam organisasi, dan sebagainya.

Selain itu, beban kerja perlu diperhitungkan secara tepat, sehingga tidak ada pegawai yang merasa beban kerjanya lebih berat dibandingkan dengan pegawai yang lain serta penugasan yang menantang kreativitas pegawai. Selanjutnya, organisasi membutuhkan kompetensi pegawai yang sesuai dengan kebutuhan kerja. Dengan demikian, tuntutan kerja, lingkungan organisasi, dan kompetensi individu, pada gilirannya akan menghasilkan perilaku kerja yang memiliki performansi tinggi.

Pengembangan sumberdaya berbasis kompetensi juga berdampak positif terhadap peningkatan kinerja organisasi Pemda Kota Bandar Lampung. Peningkatan kompetensi pegawai akan terlihat pada perubahan keterampilan, sikap, dan perilaku dalam bekerja. Hal ini juga didukung oleh hasil penelitian Katou (2009: 349) yang menyatakan bahwa pengembangan sumberdaya manusia berdampak positif terhadap kinerja organisasi.

\section{Simpulan dan Saran}

Upaya pengembangan kompetensi pegawai yang dilakukan Pemerintah Kota Bandar Lampung belum efektif dalam meningkatkan kinerja pegawai. Hal ini sebabkkan karena pengembangan pegawai masih dilakukan secara parsial dan kurang memerhatikan keterkaitan antara satu aktivitas dengan aktivitas manajemen sumberdaya manusia lainnya. Selain itu, pengembangan kompetensi ini masih mengalami hambatan dalam implementasnya karena belum terciptakan kondisi yang kondusif untuk berkembangnya budaya belajar di kalangan pegawai.

Kunci keberhasilan pengembangan sumberdaya manusia berbasis kompetensi adalah terciptakan kondisi yang kondusif untuk berkembangnya budaya belajar di kalangan pegawai. Penciptaan kondisi ini membutuhkan komitmen pimpinan dan Kepala Daerah agar gelombang perubahan budaya belajar dan budaya kerja yang akan terjadi mendapat dukungan penuh dari unsur pimpinan di daerah. Pimpinan Pemerintahan Daerah harus menciptakan kondisi yang kondusif untuk terjadinya transfer pengetahuan dan berkembangnya manajemen pengetahuan di lingkungan organisasi pemerintah daerah sehingga tacit knowledge yang dimiliki oleh pegawai bisa ditransformasikan menjadi pengetahuan yang eksplisit dan mendukung pengembangan kompetensi pegawai.

\section{Daftar Pusaka}

Aktharsha, U. Syed. (2010). A theory of Knowledge Management. Journal of Contemporary Research in Management. October - December, 2010. P 65-82

Boyatzis, Richard E. (1982). A Competent Manager: A Model for Effective 
Performance. Canada: John Wiley \& Son, Inc

Byham, William C. (t.t.). Developing Dimension/Competency-Based Human Resource System: A Monograph. Pittburghd: Development Dimensions International

Dipang, Ludfia. (2013). "Pengembangan Sumberdaya Manusia dalam Peningkatan Kinerja Karyawan Pada PT. Hasjrat Abadi Manado." Jurnal EMBA Vol.1 No.3 September 2013, Hal. 1080-1088

Duadji, Noverman. (2012). "Good Governance dalam Pemerintah Daerah". MIMBAR, Vol. 28, No. 2 (Desember, 2012): 201-209. Bandung. P2U LPPM Unisba.

Dubois, David D, William J. Rothwell, Deborah Jo King Stern, and Linda K. Kemp. (2004). Competency-Based Human Resource Management. Palo Alto: Davies-Black Publishing

Efendi, Nur. (2011). "Pengaruh Motivasi Menjadi PNS dan Tipe Kepribadian terhadap Kinerja Pegawai Pemda Kota Bandar Lampung Universitas Lampung"

Efendi, Nur (2013). "Pengaruh Kompetensi Terhadap Kinerja PNS Kantor Pemerintah Kota Bandar Lampung". Laporan Penelitian.

Hellriegel, Don, John W. Slocum. Jr, Richard W. Woodman. (2001). Organizational Behavior. Ninth edition. South-Western College Publishing. USA.

Hersona, Sonny, B.Rismayadi, Mariah,E.S. (2012). Analisis Pengaruh Pengembangan SDM terhadap Kinerja Pegawai pada Badan Kepagawaian Daerah Kabupaten Kerawang. Jurnal Manajemen Volume 09 Nomor 3 April 2012. Hal 717 - 729

Iveta, Gabčanová. (2012). Human Resources Key Performance Indicators. Journal of Competitiveness Vol. 4, Issue 1, pp. 117-128, March 2012. ISSN 1804-171X (Print), ISSN 1804-1728 (On-line), DOI: 10.7441/joc.2012.01.09

Jankingthong, Korkaew and Suthinee Rurkkhum. (2012). Factors Affecting Job Performance: A Review of Literature. Silpakorn University. Journal of Social
Sciences, Humanities, and Arts Vol.12 (2): 115-127, 2012.

Katou, Anastasia A. (2009). The Impact of Human Resource Development on Organisational Performance: Test of a Causal Model. Institute of Behavioral and Applied Management. Greece: University of Macedonia

Khan, M. Tariq, Khan, N. A., Khalid Mahmood. (2012). An Organizational Concept of Human Resource Development How Human Resource Management Scholars View 'HRD' (Literature Review). Universal Journal of Management and Social Sciences Vol. 2, No.5; May 2012. Page 36 - 47

Mangkunegara, AA. Anwar Prabu. (2010). Perilaku dan Budaya Organisasi. PT. Refika Aditama. Bandung

Manopo, Christine. (2011). Competency Based Talent And Performance Management System. Salemba Empat. Jakarta

Nawawi, Muh. (2012). Pengaruh Motivasi dan Kompetensi Tenaga Kesehatan terhadap Kinerja Pusat Kesehatan Masyarakat. MIMBAR, Vol. XXVIII, No. 1 (Juni, 2012): 93-102. Bandung: P2U, LPPM Unisba

Rampersad, Hubert K. (2006). Total Performance Scorecard; Konsep Manajemen Baru: Mencapai Kinerja dengan Integritas. Gramedia. Jakarta

Robbins, Stephen P, Organizational Behavior. Ninth edition. (2001). Prentice Hall. New Jersey.

Wahyusumidjo. (1987). Kepemimpinan dan Motivasi. Ghalia Indonesia. Jakarta

Widodo, Joko. (2001). Good Governance. Insan Cendekia. Surabaya

Yudoyono B. (2001). Otonomi Daerah Desentralisasi dan Pengembangan SD Aparatur Pemda dan Anggota DPRD. Pustaka Sinar Harapan. Jakarta

Winanti, Marliana Budhiningtias. (2011). "Pengaruh Kompetensi Terhadap Kinerja Karyawan (Survei pada PT. Frisian Flag Indonesia Wilayah Jawa Barat)." Jurnal Majalah IImiah Unikom, Volume 7. Updated Thu, 12 May 2011 21:39:11. 